\title{
ANALYSIS OF MONTHLY RATES OF RETURN IN JANUARY AND DECEMBER ON THE EXAMPLE OF SELECTED WORLD STOCK EXCHANGE INDEXES
}

In today's financial market there is a debate on the efficiency of markets between theoreticians and practitioners. While the former are trying to demonstrate the efficiency of financial markets, the second group believes that financial markets are not efficient. Evidence showing the efficiency of financial markets would also be a proof of the fact that asset portfolio managers would not be able to gain a higher rates of return than the market portfolio rates of return, in the long run. One way to demonstrate the thesis of the inefficiency of the financial markets, it is, among others, examination of calendar effects. Their existence undermines the efficient market theory and allows to construct an investment strategy which permits to obtain positive excess returns (above the rate of return of analyzed stock market index).

The article presents a study of effectiveness of 22 selected stock indices with the use of the rates of return in the months of January and December (so called "January effect" and "turn-of-the-year" effect, respectively). The portfolio replicating the stock index was bought at the close prices on the last session in one month, and sold at the close prices on the last session of the following month. The presence of market inefficiency has been demonstrated in the January in case of two indices: BUX and Nasdaq and in December in the following 15 cases: All-Ord, BUX, CAC40, DJIA, DJTA, DJUA, EOE, FTSE100, MEX-IPC, Nasdaq, Nikkei, Russel, SP500, TSE and WIG. Thus, in the case of some indices, the conclusions of other researchers has been confirmed, but other studies should be regarded as pioneering.

Keywords: market efficiency; financial market seasonality; market anomalies; January effect, December effect

\section{INTRODUCTION}

Efficient market hypothesis (EMH), the center of the influential paper of Fama, has been a cornerstone of financial economics for many decades ${ }^{2}$. Although current definitions differ from those developed by Fama, the efficiency of markets prevents systematic beating of the market, usually in a form of above-average risk-adjusted returns. The problem of the financial markets efficiency, especially of equity markets, has been discussed in a number of scientific works, which has led to a sizable set of publications examining this subject. In many empirical work dedicated to the time series analysis of rates of return and stock prices, there were found statistically significant effects of both types, i.e. calendar effects and effects associated with the size of companies. These effects are called "anomalies", because their existence testifies against market efficiency. Discussion of the most

\footnotetext{
${ }^{1}$ Krzysztof Borowski, Prof. DSc, PhD, Institute of Banking and Business Insurance, Warsaw School of Economics, Warsaw, Al. Niepodległości 162, 02-554 Warsaw, Poland, e: mail: k.borowski@upcpoczta.pl

${ }^{2}$ E. Fama, Efficient capital markets; a review of theory and empirical work, "Journal of Finance" 1970/25, p. 48 417.
} 
common anomalies in the capital markets can be found, among others, in Simson ${ }^{3}$ or Jajuga and Jajuga ${ }^{4}$.

One of the most common calendar anomalies observed on the financial markets are ${ }^{5}$ :

A) Day-of-the-week effect - daily average rates of return registered on the stock market differ for various days of the week. One of the first works dedicated to this type of effect, was developed by Kelly ${ }^{6}$, who proved that the average rate of return of US stock markets on Monday are lower than average rates of return for other days of the week. Empirical work of Hirsch ${ }^{7}$ confirmed the existence of the day-of-the-week effect. In his study, he examined behavior of the S\&P500 index in the period from June 1952 to June 1985, proving that the index close on Monday was lower in 57\% than the index close on the preceding Friday. For other days of the week, the following trend was observed - the index close on one session was higher than the index close on the previous session (Tuesdays/Monday of in $43 \%$ observations, Wednesday/Tuesday in 55,6\%, Thursday/Wednesday in 52,6\%, Friday/Thursday in 58\%). The day-of-the-week effect in the US market was also presented, among others, in the works of: Jaffe end Weterfield ${ }^{8}$, French ${ }^{9}$, Lakonishok and Maberly ${ }^{10}$. The evidence for UK market was examined by: Theobald and Price ${ }^{11}$, Jaffe and Westerfield $^{12}$, Board and Sutcliffe ${ }^{13}$, Agrawal and Tandon ${ }^{14}$, Peiro ${ }^{15}$, Mills and Coutts ${ }^{16}$, Dubois and Louvet ${ }^{17}$, Coutts and Hayes ${ }^{18}$. Peiro ${ }^{19}$, Agrawal and Tandon ${ }^{20}$, Dubois and Louvet ${ }^{21}$ and

\footnotetext{
${ }^{3}$ E. Simson, Stock market anomalies, Cambridge University Press, Cambridge 1988.

${ }^{4}$ K. Jajuga, T. Jajuga, Inwestycje, Wydawnictwo Naukowe PWN, Warszawa 2006, p. 147-149.

${ }^{5}$ J. Nowakowski, K. Borowski, Zastosowanie teorii Carolana i Fischera na rynku kapitałowym, Difin, Warszawa 2005, p. 322-329. This item contains a broad overview of the literature regarding efficiency of financial markets.

${ }^{6} \mathrm{~F}$. Kelly, Why you win or lose: the psychology of speculation, Houghton Mifflin, Boston 1930.

${ }^{7}$ Y. Hirsch, Don't sell stock on Monday, Penguin Books, New York 1987.

${ }^{8}$ J. Jaffie, R. Westerfield, C. Ma, A twist on Monday effect in stock prices: evidence from the US and foreign stock markets, "Journal of Banking and Finance" 1989/15, p. 641-650.

${ }^{9}$ K. French, Stock returns and weekend effect, "Journal of Financial Economics" 1980/8, p. 55-69.

10 J. Lakonishok, E. Maberly, The weekend effect: trading patterns of individual and institutional investors, "Journal of Finance",1990/45, p. 231-243.

${ }^{11}$ M. Theobald, V. Prince, Seasonality estimation in thin markets, "Journal of Finance” 1984/39, p. 377-392.

12 J. Jaffie, R. Westerfield, op. cit., p. 237-244.

${ }^{13}$ J. Board, C. Sutcliffe, The weekend effect in UK stock market returns, "Journal of Business, Finance and Accounting" 1988/5, p. 199-213.

${ }^{14}$ A. Agrawal, K. Tandon, Anomalies or illusions? Evidence from stock markets in eighteen countries, "Journal of International Money and Finance" 1994/13, p. 83-106.

${ }^{15}$ E. Peiro, Daily seasonality in stock returns: Further international evidence, "Economics Letters" 1994/45, p. 227-232.

${ }^{16}$ T. Mills, J. Coutts, Calendar effects in the London Stock Exchange FTSE indices, "European Journal of Finance" $1995 / 1$, p. 79-93.

${ }^{17}$ M. Dubois, P. Louvet, The day-of-the-week effect: the international evidence, "Journal of Banking and Finance" 1996/20, p. 1463-1484.

${ }^{18} \mathrm{~J}$. Coutts, P. Hayes, The weekend effect, the stock exchange account and the financial times industrial ordinary shares index 1987-1994, "Applied Financial Economics" 1999/9, p. 67-71.

${ }^{19}$ E. Peiro, op. cit., p. 227-232.

${ }^{20}$ A. Agrawal, K. Tandon, op. cit., p. 83-106.

${ }^{21}$ M. Dubois, P. Louvet, op. cit., p. 1463-1484.
} 
Kramer $^{22}$ provided evidence of negative Monday and Tuesday returns for Frankfurt exchange. In works of Solnik and Bousquet ${ }^{23}$, Agarwal and Tandon ${ }^{24}$, there was found an evidence of negative Tuesday rates of return in Paris market, while Condoyanni et al. ${ }^{25}$ and Peiro $^{26}$ demonstrated negative Monday and Tuesday rates or return on the same market and Barone $^{27}$ in Milan. Research regarding rates of return on other markets was performed in works of Kato et al. ${ }^{28}$, and also by Sutheebanjard and Premchaiswadi ${ }^{29}$. On the Polish market, findings regarding the day-of-the-week effect were conducted among others by: Buczek $^{30}$, Szyszka $^{31}$ and Czekaj et al. ${ }^{32}$.

B) Monthly effect - achieving by portfolio replicating the specified stock index, different returns in each month. The most popular monthly effect is called "January effect", i.e. the tendency to observe higher average rate of return of stock market indices in the first month of the year. For the first time, this effect was observed by $\mathrm{Keim}^{33}$, who noted that the average rate of return on stocks with small capitalization is the highest in January. In the case of large and mid-capitalization companies the effect was not so perceptible. Although January was the best single month in UK, the period from December to April consisted of months, which on average produced positive returns ${ }^{34}$. Bernstein ${ }^{35}$, taking into consideration the behavior of the US equity market in the period from 1940 to 1989, gave the interdependence between rates of returns in each month. Modern researches, e.g. $\mathrm{Gu}^{36}$ and Schwert ${ }^{37}$ show that in the last two decades of the twentieth century, phenomenon of the month-ofthe-year effect was much weaker. This fact would suggest that the discovery and dissemi-

${ }^{22}$ C. Kramer, Macroeconomic seasonality and the January effect, "Journal of Finance" 1994/49, p. $1883-1891$.

23 B. Solnik, L. Bosquet, Day-of-the-week effect on the Paris Bourse, "Journal of Banking and Finance" 1990/14, p. 461-468

${ }^{24}$ A. Agrawal, K. Tandon, op. cit., p. 83-106.

${ }^{25}$ L. Condoyanni, J. O'Hanlon, C. Ward, Day of the week effects on stock returns: international evidence, "Journal of Business Finance and Accounting” 1987/14, p. 159-174.

${ }^{26}$ E. Peiro, op. cit., p. 227-232.

${ }^{27}$ E. Barone, The Italian stock market: efficiency and calendar anomalies, "Journal of Banking and Finance" 1990/14, p. 483-510.

${ }^{28}$ K. Kato, S. Schwarz, W. Ziemba, Day of the weekend effects in Japanese stocks, [in:] Japanese Capital Markets, Ballinger, New York 1990, p. 249-281.

${ }^{29}$ P. Sutheebanjard, W. Premchaiswadi, Analysis of calendar effects: day-of-the-week effect on the Stock Exchange of Thailand (SET), "International Journal of Trade, Economics and Finance" 2010/1, p. 2010-2023.

${ }^{30}$ S. Buczek, Efektywność informacyjna rynków akcji. Teoria a rzeczywistość, Szkoła Główna Handlowa w Warszawie, Warszawa 2005, p. 51-55.

31 A. Szyszka, Wycena papierów wartościowych na rynku kapitałowym $w$ świetle finansów behawioralnych, Wydawnictwo Akademii Ekonomicznej w Poznaniu, Poznań 2007, p. 141-146.

${ }^{32}$ J. Czekaj, M. Woś, J. Żarnowski, Efektywność giełdowa rynku akcji w Polsce, Wydawnictwo Naukowe PWN, Warszawa 2001.

${ }^{33}$ D. Keim, Size-related anomalies and stock return seasonality: further empirical evidence, "Journal of Financial Economics", 1983, 12, p. 13-32.

${ }^{34}$ In works of: M. Rozeff, W. Kinney, Capital market seasonality: the case of stock returns, "Journal of Financial Economics" 1976/3, 379-402, and A. Corhay, G. Hawawini, P. Michel, Stock market anomalies, Cambridge University Press, Cambridge 1988.

35 J. Bernsten, Cycles of profit, Harpercolins, New York 1991.

${ }^{36}$ A. Gu, The declining January effect: evidence from U.S. equity markets, "Quarterly Review of Economics and Finance" 2003/2, p. 495-404

${ }^{37}$ W. Schwert, Anomalies and market efficiency, "Simon School of Business Working Paper" 2002/FR 02-13. 
nation of the monthly effect in world financial literature contributed to the increase of market efficiency.

C) Other seasonal effects - in the financial literature, there can be found following calendar effects:

1. The weekend effect $-\operatorname{Cross}^{38}$ found that markets tend to raise on Fridays and fall on Mondays. His findings generated a flood of research, e.g. Lakonishok and Le$\mathrm{vi}^{39}$, Jaffe and Westerfield ${ }^{40}$, Condoyanni et al. ${ }^{41}$ and Connolly ${ }^{42}$. The literature presents two ways of computing weekend rates of return. In the first case, Friday close and Monday open prices are used, while in the second one Friday close and Monday close prices are employed.

2. The holiday effects - markets before holidays or other trading breaks tend to rise. In the US there is a number of studies elaborating on this issue, e.g., Fields ${ }^{43}$, Ari$\mathrm{el}^{44}$, Lakonishok and Smith ${ }^{45}$ and Cadsby and Ratner ${ }^{46}$.

3. Within-the-month effect - positive rates of returns only occur in the first half of the month ${ }^{47}$.

4. Turn-of-the month effect - average rate of return calculated for the last day of the month and for three days of the next month, was higher than the average rate of return calculated for the month, for which the rate of return of only one session, was taken. Lakonishok and $\mathrm{Smidt}^{48}$ found that the four days at the turn-of-the-month averaged a cumulative rate of increase of $0,473 \%$ versus $0,0612 \%$ for and average four days. The average monthly increase was $0,349 \%$, i.e., the DJIA went down during non-turn-of-the-month period.

The aim of this article is to examine statistically significance of monthly returns in January and December, with the use of closing prices on the last sessions of two consecutive months in selected financial markets represented by the following 22 stock indices: AllOrd, AMEX, B-Shares, Bovespa Buenos, BUX, CAC40, DAX, DJIA, DJTA, DJUI, EOE, FTSE100, Hang Seng, MEX-IPC, Nasdaq, Nikkei, Rusel, SMI, SP500, TSE and WIG. The secondary aim of the work is to determine the correlation coefficients of rates of return

${ }^{38}$ F. Cross, The behavior of stock prices and Fridays and Mondays, "Financial Analyst Journal" 1973/29, p. 6769.

${ }^{39}$ J. Lakonishok, M. Levi, Weekend effect on stock returns: a note, "Journal of Finance" 1982/37, p. 883-889.

${ }^{40}$ J. Jaffie, R. Westerfield, op. cit., p. 237-244.

${ }^{41}$ L. Condoyanni, J. O’Hanlon, C. Ward, op. cit., p. 159-174.

${ }^{42}$ R. Connolly, A posterior odds analysis of the weekend effect, "Journal of Econometrics" 1991/49, p. 51-104.

${ }^{43}$ M. Fields, Security prices and stock exchange holidays in relation to short selling, "Journal of Business" 1934/7, p. 328-338.

${ }^{44}$ R. Ariel, A monthly effect in stock returns, "Journal of Financial Economics" 1987/17, p. 161-174, and idem, High stock returns before holidays: existence and evidence on possible causes, "Journal of Finance" 1990/45, p. 1611-1626.

${ }^{45}$ J. Lakonishok, S. Shmidt, Are seasonal anomalies real. A ninety-year perspective, "Review of Financial Studies" 1988/1, p. 403-425.

${ }^{46}$ C. Cadsby, M. Ratner, Turn-of-month and pre-holiday effects on stock returns: some international evidence, "Journal of Banking and Finance" 1992/16, p. 497-509.

${ }^{47}$ R. Ariel, A monthly effect..., p. 161-174 and C. Kim, J. Park, Holiday effects and stock returns: further evidence, "Journal of Financial and Quantitative Analysis" 1994/29, p. 13-32.

${ }^{48}$ Lakonishok J., Shmidt S., op. cit., p. 403-425. 
between foreign stock exchange indices and rates of return of Polish WIG index in January and February. Indices quotations are taken from the websites of Polish Brokerage House DM BOS.

The null hypothesis tested in this paper, states that the average monthly rates of return in January or December, calculated for each of 22 analyzed indices, is equal to zero (for $\alpha=5 \%$ ). Rejection of the null hypothesis would be tantamount to accept the alternative hypothesis that the average monthly rates of return in these two analyzed months, for a particular stock index, is statistically different from zero. The rejection of the null hypothesis will prove the occurrence of the calendar effect in that month.

\section{LITEARTURE REVIEW REGARDING JANUARY AND DECEMBER EF- FECTS ON EQUITY MARKETS}

For the first time the existence of the January effect was described by Wachtel ${ }^{49}$, who indicated that the average rates of return of Dow Jones Industrial Average in the period 1927 to 1942, were higher in the first month of the year than in the others. The first advanced statistical tests for the Nasdaq index, in the period 1904-1974 were carried out by Rozeff and Kenney ${ }^{50}$ - they have confirmed the existence of the January effect. Other works of Banz ${ }^{51}$, Keim ${ }^{52}$, Reinganum ${ }^{53}$ and Roll ${ }^{54}$ demonstrated the presence of this effect in the case of small- and mid-capitalization companies. Modern research of Zilca and Moller ${ }^{55}$ proved the existence of dissection of the January rates of return calculated for AMEX and Nasdaq indices. The statistically higher rates of return were registered in the first half of the month.

The presence of the January effect in other markets has been also proven in the following works: Officer ${ }^{56}$ - on the Australian market, Gultekin and Gultekin ${ }^{57}$ - on 17 different global markets, Tinic and West ${ }^{58}$ - on the Canadian market, Aggarwal et al. ${ }^{59}$, Kato and

\footnotetext{
${ }^{49}$ B. Wachtel, Certain observations on seasonal movements in stock prices, "Journal of Business of the University of Chicago" $1943 / 15$, p. 184-193.

${ }^{50}$ M. Rozeff, W. Kinney, op. cit., p. 379-402.

${ }^{51} \mathrm{R}$. Banz, The relationship between return and market value of common stocks, "Journal of Financial Economics" 1981/9, p. 3-18.

52 D. Keim, Size-related anomalies and stock return seasonality: further empirical evidence, "Journal of Financial Economics", 1983, 12, p. 13-32.

${ }^{53}$ M. Reinganum, Ten anomalous stock market behavior of small firms in January: empirical tests for tax-loss selling effects, "Journal of Financial Economics" 1983/12, p. 89-104.

${ }^{54}$ R. Roll, Vas is das? The turn-of-the-year effect and the return premia of small firms, "Journal of Portfolio Management" 1983/9, p. 18-28.

55 S. Zilca, N. Moller, The evolution of the January effect, "Journal of Banking and Finance" 2008/32, p. 447457.

${ }^{56}$ R. Officer, Seasonality in Australian capital markets: market efficiency and empirical issues, "Journal of Financial Economics 1975/2, p. 29-51.

${ }^{57}$ M. Gultekin, B. Gultekin, Stock market seasonality: international evidence, "Journal of Financial Economics", 1983,12 , p. 469-481.

${ }^{58}$ S. Tinic, R. West, Seasonality in Canadian stock prices: a test of the tax-loss selling hypothesis, "Journal of Financial and Quantitative Analysis" 1987/22, p. 561-574.

${ }^{59}$ R. Aggarwal, T. Hiraki, P. Rao, Regularities in Tokyo stock exchange security returns: P/E, size and seasonal influences, "Journal of Financial Research" 1990/13, p. 249-263.
} 
Schallheim ${ }^{60}$ and Hamori ${ }^{61}$ - on the Tokyo Stock Exchange, Nassir and Mohammad ${ }^{62}-$ on the stock markets of Hong Kong and Malaysia, Barone ${ }^{63}$ - on the Milan Stock Exchange, $\mathrm{Ho}^{64}$ - on the stock exchanges in: Hong Kong, Korea, Malaysia and the Philippines, Lauterbach and Ungar $^{65}$ - on the stock exchange in Israel, Mongoue ${ }^{66}$ - on the stock market in Taiwan, Mills et al. ${ }^{67}$ - in Greece, Bildisk ${ }^{68}$ - in Turkey, as well as Lucey and Whelan ${ }^{69}$ - in Ireland. Girardin and Liu ${ }^{70}$ demonstrated the existence of January effect on stock exchange in Shanghai. Based on the data for the period 1991 - 2003 for 8 stock exchanges of Central and Eastern Europe, Asteriou and Kovetsos ${ }^{71}$ proved the existence of a strong January effect for following markets: Polish, Hungary, Romania and Slovakia.

The December effect was also described in the following studies: Raharjo et al. ${ }^{72}$, Choudhary $^{73}$ and Fountas and Konstantinos ${ }^{74}$. In turn, Dudzinska-Baryla and Michalska ${ }^{75}$, conducted statistical tests for returns of the Warsaw Stock Exchange Index and revealed the existence of the December effect on the Polish financial market.

Among the scientific papers can also be found works that documented the absence of the January effect. Kohers and Kohli ${ }^{76}$ demonstrated that the January effect does not appear

${ }^{60}$ K. Kato, J. Schallheim, Seasonal and size anomalies in the Japanese stock market, "Journal of Financial and Quantitative Analysis" 1985/20, p. 243-260.

${ }^{61}$ S. Hamori, Seasonality and stock returns; some evidence from Japan, "Japan and the World Economy" 2001/13, p. 463-481.

${ }^{62}$ A. Nassir, S. Mohammad, The January effect of stock trader in the Kuala Lumpur Stock Exchange: an empirical analysis, "Hong Kong Journal of Business Management" 1987/5, p. 35-50.

${ }^{63}$ E. Barone, The Italian stock market: efficiency and calendar anomalies, "Journal of Banking and Finance" 1990/14, p. 483-510.

${ }^{64}$ Y. Ho, Stock returns seasonalities in Asia Pacific markets, "Journal of International Financial Management and Accounting" 1990/2, p. 47-77.

${ }^{65}$ B. Lauterbach, M. Ungar, Calendar anomalies: some perspectives from the behavior of the Israeli stock market, "Applied Financial Economics" 1992/2, p. 57-60.

${ }^{66}$ M. Mougoue, Seasonalities in the Taiwanese stock market, "American Business Review” 1996/14, p. 73-79.

${ }^{67}$ T. Mills, C. Siriopoulos, R. Markellos, D. Harizanis, Seasonality in the Athens Stock Exchange, "Applied Financial Economics" 2000/10, p. 137-142.

${ }^{68}$ R. Bildisk, Are calendar anomalies still alive? Evidence form Istanbul Stock Exchange, Istanbul Stock Exchange 2004.

${ }^{69}$ B. Lucey, S. Whelan, Monthly and semi-annual seasonality in the Irish equity market 1934-2000, "Applied Financial Economics" 2004/14, p. 203-208

${ }^{70}$ E. Girardin, Z. Liu, Bank credit and seasonal anomalies in China stock markets, "China Economic Review" 2005/6, p. 465-483.

${ }^{71}$ D. Asteriou, G. Kovetsos, Testing for the existence of the January effect in transition economies, "Applied Financial Economic Letters" 2006/2, p. 161-174.

${ }^{72}$ A. Raharjo, F. Mabaraq, F. Mundir, December effect of stock market return in Indonesia Stock Exchange 19982012, "International Journal of Science and Research" 2013/2, p. 708-711.

${ }^{73} \mathrm{~T}$. Choudhary, Month of the year effect and January effect in pre-WWI stock returns: evidence from non-linear GARCH, "International Journal of Finance \& Economics" 2001/6, p. 1-11.

${ }^{74}$ S. Fountas, S. Konstantinos, Emerging stock markets return seasonalities: the January effect and the tax-loss selling hypothesis, "Applied Financial Economics, 2002/12, p. 291-299.

75 R. Dudzińska-Baryła, E. Michalska, Efekt miesiąca a behawioralne aspekty podejmowania Decyzji, [in:] Metody i Zastosowania Badań Operacyjnych, Wydawnictwo Uniwersytetu Ekonomicznego, Katowice 2010, p. 26-42.

${ }^{76}$ T. Kohers, R. Kohli, The yearend effect in stock returns over business cycles: a technical note, "Journal of Economics and Finance" 1992/16, p. 61-68. 
in the case of monthly returns calculated for small- and medium-capitalization companies included in the SP500 index and Raj and Thurston ${ }^{77}$ showed that the January effect was not observed on the New Zealand stock exchange. The similar conclusions were reached by Hasan and $\mathrm{Raj}^{78}$ and $\mathrm{Li}$ and $\mathrm{Liu}^{79}$. Raj and Kumari ${ }^{80}$ proved that on the following stock exchanges: Bombay Stock Exchange and National Stock Exchange in India, the January effect was not registered, but the effect of statistically higher rates of return took place in April. The existence of strong January effect and weaker April effect on 18 different stock exchanges was revealed by Agrawal and Tandon ${ }^{81}$ - their results were consistent with the previous results obtained by Gultekin and Gultekin ${ }^{82}$.

Ritter $^{83}$ suggested that at the end of the calendar year high volatility of small- and medium-capitalization companies, which main shareholders are individual investors, is the result of their investment portfolios reconstruction. For instance, the ratio of buy orders to sell orders, placed by individual investors at the Merrill Lynch brokerage house, was high in January, and low in the end of December. Thus, the author tries to explain the existence of the January effect. In turn, the occurrence of the December effect might be explained by payment of capital gains tax. Individual investors liquidate long positions in their portfolios, on which negative rates of return were registered, in order to minimize capital gain tax. Similar approach is presented by Poterba and Weisbenner ${ }^{84}$, Sias and Starks ${ }^{85}$, Chen and Singal ${ }^{86}$, and in the case of small-capitalization companies by Constatidenes ${ }^{87}$.

Investors closing their positions in declining in value assets, contribute to deeper fall in assets' market prices ${ }^{88}$. Ogden ${ }^{89}$ justifies the existence of the January effect with the use of the company's request for certain cash transactions at the end of the year in order to achieve

${ }^{77}$ M. Raj, D. Thurston, January or April? Test of the turn-of-the-year-effect in the New Zealand stock market, "Applied Economics Letters" 1994/18, p. 81-83.

${ }^{78}$ T. Hasan, M. Raj, An examination of the tax loss selling behavior in a deregulated pacific financial market. "American Business Review" 2001/19, p. 100-105.

${ }^{79}$ B. Li, B. Liu, Monthly seasonality in the New Zealand stock market, "International Journal of Business, Management and Economic Research" 2010/1, p. 1116-1121.

${ }^{80}$ M. Raj, D. Kumari, D., Day-of-the-week and other market anomalies in the Indian stock market, "International Journal of Emerging Markets" 2006/1, p. 235-246.

${ }^{81}$ A. Agrawal, K. Tandon, op. cit., p. 83-106.

${ }^{82}$ M. Gultekin, B. Gultekin, op. cit., p. 469-481.

${ }^{83} \mathrm{~J}$. Ritter, An explanation to the turn of the year effect, "University of Michigan, Graduate School of Business Administration, Working Paper" 1987, http://dx.doi.org/10.2307/2328193.

${ }^{84}$ J. Poterba, S. Weisbenner, Capital gains tax rules, tax-loss trading, and turn-of-the-year returns, "Journal of Finance" 2001/56, p. 353-368.

${ }^{85}$ R. Sias, L. Starks, Institutions and individuals at the turn-of-the-year, "Journal of Finance" 1997/52, p. 15431562

${ }^{86}$ H. Chen, V. Singal, Role of speculative short sales in price formation: case of the weekend effect, "Journal of Finance" 2003/4, p. 685-705.

${ }^{87}$ G. Constantinides, Optimal stock-trading with personal taxes: implications for prices and the abnormal January returns, "Journal of Financial Economics" 1984/13, p. 65-69.

${ }^{88}$ M. Reinganum, Ten anomalous stock market behavior of small firms in January: empirical tests for tax-loss selling effects, "Journal of Financial Economics" 1983/12, p. 89-104, and R. Roll, Vas is das? The turn-of-theyear effect and the return premia of small firms, "Journal of Portfolio Management" 1983/9, p. 18-28, and J. Ritter, The buying and selling behavior of individual investors at the turn of the year, "Journal of Finance" 1988/43, p. 701-717.

${ }^{89} \mathrm{~J}$. Ogden, Turn-of month evaluations of liquid profits and stock returns: a common explanation for the monthly and January effects, ,Journal of Finance” 1990/45, p. 1259-1272. 
an adequate liquidity. Chang and Pinegar tried to explain the January effect pointing to the specific macroeconomic data and risk premium seasonality ${ }^{90}$. Similar approach is represented, among others by Kramer ${ }^{91}$. Kohers and Kohli ${ }^{92}$ explained the occurrence of January effect referring to anomalies in business cycles. According to Ligon $^{93}$, higher rates of return in January are the result of an increase in the trading volume on the financial markets and lower real interest rates. Another explanation for the occurrence of the seasonality effects on the different stock exchanges (including the Warsaw Stock Exchange), may be the capital inflow to the various markets, including emerging markets, e.g. Poland. In this way one can justify positive returns in January (January effect) or in $\mathrm{May}^{94}$. The correlation of rates of return observed on various emerging markets and correlation of capital flows registered between them, was investigated among others by Longin and Solnik ${ }^{95}$. In turn, capital transfers between the emerging markets were examined by Bekaert and Harvey ${ }^{96}$. Finally, it should be noted that the presence of positive returns during certain days of the week or month, and negative in others, is a characteristic feature of the financial markets and demonstrates the ineffectiveness of the analyzed market. This approach can be found in the work of French ${ }^{97}$, who does not give reasons for negative returns in the US market, considering them to be characteristic for this market and providing its inefficiency. A similar thesis presents Rogalski ${ }^{98}$.

\section{DATA AND METHODS}

The calculation of the closing price for two consecutive sessions is often applied in the process of analyzing the seasonal effects of rates of return. In the case of monthly seasonal effects, the rate of return will be computed with the use of closing value of the analyzed market index on the last session of the month $I_{t}$, in relation to the closing value of the same index on the last session in the preceding month $I_{t-1}$ :

\footnotetext{
${ }^{90}$ C. Chang, L. Pinegar, Seasonal fluctuations in industrial production and stock market seasonals, "Journal of Financial and Quantitative Analysis" 1989/24, p. 59-75, and C. Chang, L. Pinegar, Stock market seasonal and prespecified multifactor pricing relations, "Journal of Financial and Quantitative Analysis" 1990/25, p. 517533.

${ }^{91}$ C. Kramer, op. cit., p. 1883-1891.

${ }_{92}$ T. Kohers, R. Kohli, The yearend effect in stock returns over business cycles: a technical note, "Journal of Economics and Finance" 1992/16, p. 61-68.

${ }_{93} \mathrm{~J}$. Ligon, A simultaneous test of competing theories regarding the January effect, "Journal of Financial Research" 1997/20, p. 13-32.

${ }^{94}$ E.g: P. Polwitoon, O. Tawatnuntachai, Emerging market bond funds: a comprehensive analysis, „Financial Review" 2008/1, p. 51-84; O. Al-Khazali, E. Koumanakos, C. Pyun, Calendar anomaly in the Greek stock market: stochastic dominance analysis, "International Review of Financial Analysis" 2008/3, p. 461-474 T. Suppa-Aim, Mutual fund performance in emerging markets: the case of Thailand, University of Birmingham, Working paper 2010; S. Claessens, S. Dasgupta, J. Glenn, Return behavior in emerging stock markets, "The World Bank Economic Review" 1995/1, p. 1-17.

${ }^{95} \mathrm{~F}$. Login, B. Solnik, Is the correlation in international equity returns constant: 1960-1990?, "Journal of International Money and Finance" 1995/1, p. 3-26.

${ }^{96}$ G. Bekaert, C. Harvey, Foreign speculators and emerging equity markets, "Journal of Finance" 2000/2, p. 565614.

${ }^{97}$ K. French, op. cit., p. 55-69.

${ }^{98}$ M. Rogalski, Discussion to Keim i Stambaugh, "Journal of Finance” 1984/3, p. 1603-1614.
} 


$$
r=\frac{I_{t}-I_{t-1}}{I_{t-1}}
$$

The following 22 stock market indices were selected for the study: All-Ordinaries (Sydney Stock Exchange), AMEX (American Stock Exchange), B-shares (Shanghai Stock Exchange), Bovespa (Sao Paulo Stock Exchange), Bueons (Bueons Aires Stock Exchange, BUX (Budapest Stock Exchange), CAC 40 (Paris Stock Exchange), DAX (Frankfurt Stock Exchange), DJIA (Dow Jones Industrial Average), DJTA (Dow Jones Transportation Average), DJUA (Dow Jones Utility Average), EOE (Amsterdam Stock Exchange), FTSE 100 (London Stock Exchange), Hang Seng (Hong Kong Stock Exchange), MEX-IPC (Mexican Stock Exchange), Nasdaq, Nikkei (Tokyo Stock Exchange), Russel (US stock market index), SMI (Zurich Stock Exchange), SP500 (Standard \& Poor's 500), TSE 300 (Toronto Stock Exchange), WIG (Warsaw Stock Exchange). Therefore the study group of exchange indexes contains indices of developed countries (e.g. DJIA, TSE 300, SP500), as well as market indices classified to the group of emerging markets (e.g. WIG, BUX, MEX-IPC, Bovespa, Buenos).

Due to the different initial dates of publication of each index, and taking into account the content of the database provided by the brokerage house DM BOS, the analysis of the seasonality effects for each index will take place in different time intervals. The Table 1 presents the first year of historic price data available in the data base. For all examined indices the end date of the analyzed time span was 31.12.2014. For example, in the case of the CAC40 index seasonality effect analysis period extended from January 1995 to December 2014, which is an equivalent of 20 monthly returns in January and December. The longest available time series covering more than 40 years, allowed to calculate 44 returns for Nasdaq index, and 45 for following indices: SP500, Nikkei and DJIA. Transaction costs were not included in the process of analysis of monthly rates of return.The index markings are in accordance with generally accepted abbreviations in the information service of the brokerage house.

After the calculation of December and January rates of return over the analyzed time span for each of 22 analyzed indices, the null hypothesis will be tested. The null hypothesis states that the average monthly rates of return is equal to zero (for $\alpha=5 \%$ ). Rejection of the null hypothesis would be tantamount to accept the alternative hypothesis that the average monthly rates of return, for a particular stock index is statistically different from zero, which will prove the occurrence of the calendar effect in that month, based on the closing prices of the two consecutive months.

The presence of calendar anomalies in the analyzed month, taking into consideration only the closing prices on the last trading session in two consecutive months, in case of the examined stock index, allows investors to achieve superior returns in the long run (which can be used in practice ${ }^{99}$ ) and provides evidence for the existence of anomalies and witnesses against the theory of financial market efficiency. Thus, the results of research, can be considered as a voice in the discussion of the efficient market hypothesis, presented by Fama ${ }^{100}$.

\footnotetext{
${ }^{99}$ In the form of investment strategy based on replicating and index portfolio at the close price on the last session in November (December) and liquidating the position at the close prices during the last session in December (January).

${ }^{100}$ E. Fama, Efficient capital markets; a review of theory and empirical work, "Journal of Finance" 1970/25, p. 483-417.
} 
Table 1 . The beginning year of the calculated monthly rates of return for analyzed indices and the number of monthly returns for each index

\begin{tabular}{|c|c|c|c|c|c|c|c|c|c|c|c|c|c|c|c|c|c|c|c|c|c|c|}
\hline Index & 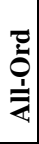 & $\sum_{4}^{\infty}$ & $\frac{\tilde{s}}{\tilde{z}}$ & $\begin{array}{l}0 \\
0 \\
0 \\
0 \\
0 \\
0\end{array}$ & $\stackrel{\mathscr{0}}{\stackrel{0}{0}}$ & $\underset{\infty}{x}$ & 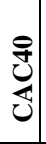 & $\stackrel{x}{a}$ & $\Xi$ & E & 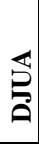 & 됭 & 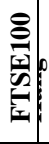 & 象 & $\begin{array}{l}\mathbf{y} \\
\mathbf{y} \\
\mathbf{y} \\
\mathbf{y} \\
\mathbf{y}\end{array}$ & 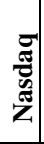 & 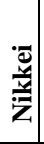 & 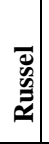 & $\sum_{\boldsymbol{S}}$ & $\begin{array}{l}8 \\
\frac{8}{n} \\
\bar{n}\end{array}$ & $\stackrel{5}{\mathscr{2}}$ & שِ \\
\hline First year & ஓ & $\check{2}$ & ฉે & $\stackrel{n}{2}$ & $\hat{\sigma}$ & $\check{2}$ & $\check{2}$ & $\stackrel{n}{2}$ & $\stackrel{?}{\Omega}$ & $\stackrel{n}{2}$ & $\stackrel{n}{2}$ & $\stackrel{n}{2}$ & ๙̊ & $\begin{array}{l}\infty \\
\stackrel{=}{\infty}\end{array}$ & মे & $\stackrel{N}{a}$ & $\stackrel{\circ}{\circ}$ & 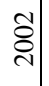 & $\stackrel{n}{2}$ & $\stackrel{\circ}{2}$ & ஓ & $\stackrel{2}{\Omega}$ \\
\hline $\begin{array}{l}\text { Number of rates of return } \\
\text { in the calculations }\end{array}$ & 26 & 20 & 17 & 20 & 19 & 20 & 20 & 20 & 45 & 20 & 20 & 20 & 23 & 28 & 21 & 44 & 45 & 14 & 20 & 45 & 26 & 23 \\
\hline
\end{tabular}

Source: own calculations

\section{ANALYSIS OF RESULTS}

The results of the analysis for each index are summarized in Tables 2 . In the case the number of observation was lower than 30, Student's t-statistics was applied, otherwise normal distribution was used. The nominal rate of return was calculated as the product of the monthly average rates of return in a given month and the number 12 . The following principle was adopted in the row "Null hypothesis verification" in the Table 2 to Table 5.

Table 2. Basic statistical data obtained for January rates of return for the first 11 out of the 22 analyzed stock indices

\begin{tabular}{|c|c|c|c|c|c|c|c|c|c|c|c|}
\hline Index & All-Ord & AMEX & B-Shares & Bovespa & Buenos & BUX & CAC40 & DAX & DJIA & DJTA & DJUA \\
\hline Monthly average rate of return & 0,0027 & $-0,0031$ & 0,0395 & 0,0255 & 0,0712 & 0,0603 & 0,0068 & 0,0062 & 0,0130 & $-0,0030$ & $-0,0043$ \\
\hline Standard error & 0,0081 & 0,0086 & 0,0368 & 0,0227 & 0,0349 & 0,0268 & 0,0137 & 0,0144 & 0,0079 & 0,0158 & 0,0105 \\
\hline Median & 0,0131 & $-0,0046$ & 0,0183 & $-0,0195$ & 0,0381 & 0,0549 & 0,0226 & 0,0236 & 0,0114 & 0,0161 & $-0,0029$ \\
\hline Standard deviation & 0,0406 & 0,0374 & 0,1470 & 0,0988 & 0,1481 & 0,1168 & 0,0595 & 0,0628 & 0,0524 & 0,0689 & 0,0459 \\
\hline Variance & 0,0017 & 0,0014 & 0,0216 & 0,0098 & 0,0219 & 0,0136 & 0,0035 & 0,0039 & 0,0027 & 0,0047 & 0,0021 \\
\hline Kurtosis & 1,3154 & $-0,6237$ & 1,0117 & $-1,0788$ & 2,5852 & 2,0760 & $-0,0715$ & 0,8971 & 0,7808 & 0,3976 & 1,3692 \\
\hline Skewness & $-1,0011$ & 0,2770 & 0,7471 & 0,7578 & 1,3294 & 1,2948 & $-0,6590$ & $-0,9090$ & 0,6304 & $-0,8476$ & 0,4522 \\
\hline Range & 0,1753 & 0,1262 & 0,5683 & 0,2797 & 0,6221 & 0,4578 & 0,2193 & 0,2466 & 0,2325 & 0,2553 & 0,2088 \\
\hline Minimum & $-0,1128$ & $-0,0648$ & $-0,1733$ & $-0,0751$ & $-0,1352$ & $-0,1052$ & $-0,1326$ & $-0,1507$ & $-0,0884$ & $-0,1616$ & $-0,0967$ \\
\hline Maksimum & 0,0625 & 0,0614 & 0,3950 & 0,2046 & 0,4868 & 0,3526 & 0,0868 & 0,0959 & 0,1441 & 0,0937 & 0,1122 \\
\hline Sum & 0,0668 & $-0,0595$ & 0,6314 & 0,4843 & 1,2814 & 1,1454 & 0,1295 & 0,1169 & 0,5724 & $-0,0579$ & $-0,0819$ \\
\hline Number of observations & 26 & 20 & 17 & 20 & 19 & 20 & 20 & 20 & 45 & 20 & 20 \\
\hline Confidence level $(95,0 \%)$ & 0,0168 & 0,0180 & 0,0783 & 0,0476 & 0,0737 & 0,0563 & 0,0287 & 0,0303 & 0,0159 & 0,0332 & 0,0221 \\
\hline Null hypothesis verification & TRUE & TRUE & TRUE & TRUE & TRUE & FALSE & TRUE & TRUE & TRUE & TRUE & TRUE \\
\hline Nominal rate of return (\%) & $3,20 \%$ & $-3,76 \%$ & $47,36 \%$ & $30,58 \%$ & $85,43 \%$ & $72,34 \%$ & $8,18 \%$ & $7,38 \%$ & $15,61 \%$ & $-3,66 \%$ & $-5,17 \%$ \\
\hline
\end{tabular}

The null hypothesis verification: "TRUE" - there is no reason to reject the null hypothesis, "FALSE" - the null hypothesis should be rejected in favor of the alternative hypothesis.

Source: own calculations

\footnotetext{
${ }^{101}$ Due to the fact that the first session on the Warsaw Stock Exchange took place on 04.16.1991, the first monthly rate of return in January for the WIG index was calculated in January of 1992.
} 
If there was no reason to reject the null hypothesis, then the word "TRUE" was placed in the cell, but when the null hypothesis was rejected in favor of the alternative hypothesis the word "FALSE" was used.

For January average rates of return, the null hypothesis was rejected for the following 2 indices: BUX and Nasdaq. For the first of these indices, the monthly average rate of return is equal to $6,03 \%$, while for the second it mounted to $2,70 \%$. The first of these two indices BUX is classified in the emerging markets segment, while the Nasdaq index represents one of the stock markets of developed countries. Average monthly rates of return were positive in the case of 15 indices and negative for 7 indices. The highest value of the nominal rate of return equal to $85,43 \%$ was observed in the case of Buenos index, and the lowest and equal to $-12,22 \%$ for FTSE100.

Table 3. Basic statistical data obtained for January rates of return for the second 11 out of the 22 analyzed stock indices

\begin{tabular}{|l|r|r|r|r|r|r|r|r|r|r|r|}
\hline \multicolumn{1}{|c|}{ Index } & EOE & FTSE100 & Hang Seng & MEX-IPC & Nasdaq & Nikkei & Russel & SMI & SP500 & TSE & WIG \\
\hline $\begin{array}{l}\text { Monthly } \\
\text { average rate of } \\
\text { return }\end{array}$ & $-0,0035$ & $-0,0102$ & $-0,0022$ & 0,0006 & 0,0270 & 0,0154 & $-0,0040$ & 0,0011 & 0,0129 & 0,0063 & 0,0442 \\
\hline Standard error & 0,0121 & 0,0097 & 0,0152 & 0,0176 & 0,0097 & 0,0081 & 0,0162 & 0,0113 & 0,0076 & 0,0071 & 0,0270 \\
\hline Median & 0,0108 & $-0,0046$ & $-0,0067$ & 0,0044 & 0,0305 & 0,0304 & $-0,0111$ & 0,0057 & 0,0177 & 0,0080 & 0,0092 \\
\hline $\begin{array}{l}\text { Standard } \\
\text { deviation }\end{array}$ & 0,0525 & 0,0456 & 0,0789 & 0,0786 & 0,0638 & 0,0535 & 0,0582 & 0,0493 & 0,0503 & 0,0356 & 0,1296 \\
\hline Variance & 0,0028 & 0,0021 & 0,0062 & 0,0062 & 0,0041 & 0,0029 & 0,0034 & 0,0024 & 0,0025 & 0,0013 & 0,0168 \\
\hline Kurtosis & 1,6995 & $-0,2357$ & $-0,7096$ & $-0,7466$ & $-0,4764$ & 0,7256 & $-0,4929$ & $-0,0403$ & 0,0143 & $-0,5113$ & 1,9587 \\
\hline Skewness & $-1,4567$ & $-0,4762$ & $-0,0696$ & $-0,0582$ & 0,1952 & $-0,1802$ & $-0,0235$ & $-0,2377$ & 0,2842 & $-0,4724$ & 1,0822 \\
\hline Range & 0,1913 & 0,1598 & 0,3001 & 0,2757 & 0,2662 & 0,2735 & 0,2011 & 0,1797 & 0,2174 & 0,1267 & 0,5493 \\
\hline Minimum & $-0,1443$ & $-0,0955$ & $-0,1567$ & $-0,1262$ & $-0,0989$ & $-0,1121$ & $-0,1120$ & $-0,0959$ & $-0,0857$ & $-0,0670$ & $-0,1766$ \\
\hline Maksimum & 0,0470 & 0,0643 & 0,1434 & 0,1494 & 0,1672 & 0,1615 & 0,0891 & 0,0837 & 0,1318 & 0,0597 & 0,3727 \\
\hline Sum & $-0,0670$ & $-0,2240$ & $-0,0588$ & 0,0118 & 1,1605 & 0,6754 & $-0,0520$ & 0,0201 & 0,5695 & 0,1575 & 1,0177 \\
\hline $\begin{array}{l}\text { Number of } \\
\text { bbservations }\end{array}$ & 20 & 23 & 28 & 21 & 44 & 45 & 14 & 20 & 45 & 26 & 23 \\
\hline $\begin{array}{l}\text { Confidence } \\
\text { level (95,0\%) }\end{array}$ & 0,0253 & 0,0202 & 0,0312 & 0,0368 & 0,0196 & 0,0163 & 0,0352 & 0,0238 & 0,0153 & 0,0147 & 0,0560 \\
\hline $\begin{array}{l}\text { Null hypothesis } \\
\text { verification }\end{array}$ & \multicolumn{1}{|c|}{ TRUE } & \multicolumn{1}{|c|}{ TRUE } & TRUE & TRUE & FALSE & TRUE & TRUE & TRUE & TRUE & TRUE & TRUE \\
\hline $\begin{array}{l}\text { Nominal rate } \\
\text { of return (\%) }\end{array}$ & $-\mathbf{- 4 , 2 3 \%}$ & $-\mathbf{1 2 , 2 2 \%}$ & $-\mathbf{- 2 , 6 1 \%}$ & $\mathbf{0 , 7 1 \%}$ & $\mathbf{3 2 , 3 9 \%}$ & $\mathbf{1 8 , 4 2 \%}$ & $\mathbf{- 4 , 8 0 \%}$ & $\mathbf{1 , 2 7 \%}$ & $\mathbf{1 5 , 5 3 \%}$ & $\mathbf{7 , 5 6 \%}$ & $\mathbf{5 3 , 1 0 \%}$ \\
\hline
\end{tabular}

The null hypothesis verification: "TRUE" - there is no reason to reject the null hypothesis, "FALSE" - the null hypothesis should be rejected in favor of the alternative hypothesis.

Source: own calculations 
Table 4. Basic statistical data obtained for December rates of return for the first 11 out of the 22 analyzed stock indices

\begin{tabular}{|l|r|r|r|r|r|r|r|r|r|r|r|}
\hline \multicolumn{1}{|c|}{ Index } & All-Ord & AMEX & B-Shares & Bovespa & \multicolumn{1}{c|}{ Buenos } & \multicolumn{1}{c|}{ BUX } & CAC40 & DAX & DJIA & DJTA & DJUA \\
\hline $\begin{array}{l}\text { Monthly average } \\
\text { rate of return }\end{array}$ & 0,0188 & 0,0096 & 0,0336 & 0,0357 & 0,0531 & 0,0394 & 0,0199 & 0,0247 & 0,0167 & 0,0161 & 0,0260 \\
\hline Standard error & 0,0051 & 0,0061 & 0,0235 & 0,0199 & 0,0288 & 0,0161 & 0,0089 & 0,0125 & 0,0046 & 0,0069 & 0,0060 \\
\hline Median & 0,0226 & 0,0094 & 0,0179 & 0,0454 & 0,0524 & 0,0247 & 0,0237 & 0,0290 & 0,0143 & 0,0214 & 0,0298 \\
\hline $\begin{array}{l}\text { Standard } \\
\text { deviation }\end{array}$ & 0,0259 & 0,0271 & 0,0967 & 0,0888 & 0,1255 & 0,0718 & 0,0400 & 0,0558 & 0,0306 & 0,0310 & 0,0270 \\
\hline Variance & 0,0007 & 0,0007 & 0,0094 & 0,0079 & 0,0158 & 0,0052 & 0,0016 & 0,0031 & 0,0009 & 0,0010 & 0,0007 \\
\hline Kurtosis & $-0,1563$ & 0,8410 & 1,4421 & 3,4964 & 5,6875 & 0,3762 & 1,9749 & 5,1213 & 0,4667 & $-0,6056$ & $-0,7625$ \\
\hline Skewness & $-0,2574$ & $-0,1870$ & 1,2255 & $-0,6021$ & 1,7505 & 1,0955 & $-0,0707$ & 0,0005 & 0,1823 & $-0,3596$ & $-0,3459$ \\
\hline Range & 0,0999 & 0,1210 & 0,3599 & 0,4544 & 0,5844 & 0,2420 & 0,1944 & 0,3089 & 0,1570 & 0,1142 & 0,0959 \\
\hline Minimum & $-0,0316$ & $-0,0535$ & $-0,0817$ & $-0,2140$ & $-0,1254$ & $-0,0396$ & $-0,0790$ & $-0,1288$ & $-0,0623$ & $-0,0431$ & $-0,0300$ \\
\hline Maksimum & 0,0683 & 0,0675 & 0,2782 & 0,2404 & 0,4591 & 0,2024 & 0,1155 & 0,1801 & 0,0947 & 0,0710 & 0,0659 \\
\hline Sum & 0,4890 & 0,1919 & 0,5720 & 0,7146 & 1,0097 & 0,7880 & 0,3975 & 0,4942 & 0,7520 & 0,3224 & 0,5206 \\
\hline $\begin{array}{l}\text { Number of } \\
\text { observations }\end{array}$ & 26 & 20 & 17 & 20 & 19 & 20 & 20 & 20 & 45 & 20 & 20 \\
\hline $\begin{array}{l}\text { Confidence level } \\
\text { (95,0\%) }\end{array}$ & 0,0105 & 0,0127 & 0,0497 & 0,0416 & 0,0605 & 0,0336 & 0,0187 & 0,0261 & 0,0092 & 0,0145 & 0,0126 \\
\hline $\begin{array}{l}\text { Null hypothesis } \\
\text { verification }\end{array}$ & $\mathbf{F A L S Z}$ & PRAWDA & $\mathbf{P R A W D A}$ & PRAWDA & PRAWDA & FALSZ & FALSZ & PRAWDA & FALSZ & FALSZ & FALSZ \\
\hline $\begin{array}{l}\text { Nominal rate of } \\
\text { return (\%) }\end{array}$ & $\mathbf{2 2 , 5 7 \%}$ & $\mathbf{1 1 , 5 1 \%}$ & $\mathbf{4 0 , 3 8 \%}$ & $\mathbf{4 2 , 8 8 \%}$ & $\mathbf{4 7 , 2 8 \%}$ & $\mathbf{2 3 , 8 5 \%}$ & $\mathbf{2 9 , 6 5 \%}$ & $\mathbf{2 0 , 0 5 \%}$ & $\mathbf{1 9 , 3 4 \%}$ & $\mathbf{3 1 , 2 3 \%}$ & $\mathbf{3 2 , 5 0 \%}$ \\
\hline
\end{tabular}

The null hypothesis verification: "TRUE" - there is no reason to reject the null hypothesis, "FALSE" - the null hypothesis should be rejected in favor of the alternative hypothesis.

Source: own calculations

In the case of monthly rates of return in December the null hypothesis was rejected for the 15 indices (in parentheses are given respectively, the monthly average rate of return and the level of confidence): All-Ord $(1,88 \%, 1,05 \%)$, BUX $(3,94 \% ; 3,36 \%)$, CAC40 $(1,99 \%$; $1,87 \%)$, DJIA $(1,67 \% ; 0,92 \%)$, DJTA $(1,61 \% ; 1,45 \%)$, DJUA $(2,60 \% ; 1,26 \%)$, EOE $(2,71 \%$, $2,25 \%)$, the FTSE100 (2,15\%, 1,27\%), MEX-IPC (3,49\%, 2,27\%), Nasdaq $(1,94 \%, 1,62 \%)$, Nikkei $(1,74 \%, 1,54 \%)$, Russel $(2,41 \%, 2,12 \%)$, SP500 (1,72\%, 0,98\% ), TSE $(2,06 \%$, $1,11 \%)$ and WIG $(4,34 ; 4,14 \%)$. Among these indices, are classified stock exchange indices of both group of countries: developed countries (e.g. DJIA, DJUA, FTSE100) and the emerging markets (eg. WIG, BUX). Monthly average rates of return in December were positive in the case of all analyzed indices. The highest nominal rate of return of 52,11\% was observed for WIG index and the lowest and equal to $11,51 \%$ for AMEX. 
Table 5. Basic statistical data obtained for December rates of return for the second 11 out of the 22 analyzed stock indices

\begin{tabular}{|l|r|r|r|r|r|r|r|r|r|r|c|}
\hline \multicolumn{1}{|c|}{ Index } & \multicolumn{1}{c|}{ EOE } & FTSE100 & Hang Seng & MEX-IPC & Nasdaq & Nikkei & Russel & SMI & SP500 & TSE & WIG \\
\hline $\begin{array}{l}\text { Monthly } \\
\text { average rate of } \\
\text { return }\end{array}$ & 0,0271 & 0,0215 & 0,0227 & 0,0349 & 0,0194 & 0,0174 & 0,0241 & 0,0118 & 0,0172 & 0,0206 & 0,0434 \\
\hline Standard error & 0,0107 & 0,0061 & 0,0128 & 0,0109 & 0,0080 & 0,0077 & 0,0098 & 0,0089 & 0,0049 & 0,0054 & 0,0200 \\
\hline Median & 0,0279 & 0,0236 & 0,0154 & 0,0376 & 0,0078 & 0,0185 & 0,0225 & 0,0194 & 0,0147 & 0,0195 & 0,0401 \\
\hline $\begin{array}{l}\text { Standard } \\
\text { deviation }\end{array}$ & 0,0480 & 0,0293 & 0,0677 & 0,0498 & 0,0533 & 0,0514 & 0,0366 & 0,0396 & 0,0327 & 0,0274 & 0,0958 \\
\hline Variance & 0,0023 & 0,0009 & 0,0046 & 0,0025 & 0,0028 & 0,0026 & 0,0013 & 0,0016 & 0,0011 & 0,0008 & 0,0092 \\
\hline Kurtosis & 2,5739 & 1,2676 & 10,7333 & 2,0351 & 3,9122 & $-0,3250$ & 0,6021 & 1,8865 & 1,0266 & 5,9956 & 8,8003 \\
\hline Skewness & $-0,7636$ & $-0,3472$ & 2,6673 & 0,1539 & 1,3402 & $-0,0171$ & $-0,3703$ & $-0,9893$ & 0,5114 & 1,4649 & 2,4802 \\
\hline Range & 0,2236 & 0,1343 & 0,3771 & 0,2461 & 0,3166 & 0,2111 & 0,1360 & 0,1799 & 0,1719 & 0,1489 & 0,4653 \\
\hline Minimum & $-0,1085$ & $-0,0549$ & $-0,0743$ & $-0,0842$ & $-0,0969$ & $-0,0826$ & $-0,0573$ & $-0,0951$ & $-0,0603$ & $-0,0305$ & $-0,0625$ \\
\hline Maksimum & 0,1151 & 0,0794 & 0,3028 & 0,1619 & 0,2198 & 0,1285 & 0,0788 & 0,0848 & 0,1116 & 0,1184 & 0,4028 \\
\hline Sum & 0,5417 & 0,4946 & 0,6360 & 0,7338 & 0,8543 & 0,7851 & 0,3369 & 0,2353 & 0,7755 & 0,5358 & 0,9987 \\
\hline $\begin{array}{l}\text { Number of } \\
\text { observations }\end{array}$ & 20 & 23 & 28 & 21 & 44 & 45 & 14 & 20 & 45 & 26 & 23 \\
\hline $\begin{array}{l}\text { Confidence } \\
\text { level (95,0\%) }\end{array}$ & 0,0225 & 0,0127 & 0,0262 & 0,0227 & 0,0162 & 0,0154 & 0,0212 & 0,0185 & 0,0098 & 0,0111 & 0,0414 \\
\hline $\begin{array}{l}\text { Null hypothesis } \\
\text { verification }\end{array}$ & $\mathbf{F A L S Z}$ & $\mathbf{F A L S Z}$ & $\mathbf{P R A W D A}$ & $\mathbf{F A L S Z}$ & $\mathbf{F A L S Z}$ & $\mathbf{F A L S Z}$ & $\mathbf{F A L S Z}$ & PRAWDA & FALSZ & FALSZ & FALSZ \\
\hline $\begin{array}{l}\text { Nominal rate } \\
\text { of return (\%) }\end{array}$ & $\mathbf{3 2 , 5 0 \%}$ & $\mathbf{2 5 , 8 0 \%}$ & $\mathbf{2 7 , 2 6 \%}$ & $\mathbf{4 1 , 9 3 \%}$ & $\mathbf{2 3 , 3 0 \%}$ & $\mathbf{2 0 , 9 4 \%}$ & $\mathbf{2 8 , 8 8 \%}$ & $\mathbf{1 4 , 1 2 \%}$ & $\mathbf{2 0 , 6 8 \%}$ & $\mathbf{2 4 , 7 3 \%}$ & $\mathbf{5 2 , 1 1 \%}$ \\
\hline
\end{tabular}

The null hypothesis verification: "TRUE" - there is no reason to reject the null hypothesis, "FALSE" - the null hypothesis should be rejected in favor of the alternative hypothesis.

Source: own calculations

Table 6 presents the percentage of positive monthly rates of return in January in decreasing order. In all of the analyzed cases, the percentage of positive returns was greater than $50 \%$. The most common positive rate of return was recorded for AMEX - 80\%. On the second place were registered two indices: B-Shares and Bovespa $-75 \%$ of positive monthly rates of return, and on the third place three indices: Bueons, BUX, CAC40 and DAX $70 \%$. Least likely of all analyzed indices, positive monthly returns were observed in the case of the WIG index - in $52 \%$ of all monthly rates of return. 
Table 6. Number and percentage of positive and negative rates of return in January for the analyzed stock indices sorted in descending order for the percentage of positive returns.

\begin{tabular}{|c|c|c|c|c|c|c|}
\hline Index & $\begin{array}{c}\text { Total number of } \\
\text { calculated } \\
\text { monthly returns }\end{array}$ & $\begin{array}{c}\text { Number of } \\
\text { positive monthly } \\
\text { returns }\end{array}$ & $\begin{array}{l}\text { Number of } \\
\text { negative monthly } \\
\text { returns }\end{array}$ & $\begin{array}{l}\text { Percentage of } \\
\text { positive monthly } \\
\text { returns }\end{array}$ & $\begin{array}{l}\text { Percentage of } \\
\text { negative monthly } \\
\text { returns }\end{array}$ & Sum \\
\hline AMEX & 20 & 16 & 4 & $80,00 \%$ & $20,00 \%$ & $100 \%$ \\
\hline B-Shares & 20 & 15 & 5 & $75,00 \%$ & $25,00 \%$ & $100 \%$ \\
\hline Bovespa & 20 & 15 & 5 & $75,00 \%$ & $25,00 \%$ & $100 \%$ \\
\hline Buenos & 20 & 14 & 6 & $70,00 \%$ & $30,00 \%$ & $100 \%$ \\
\hline BUX & 20 & 14 & 6 & $70,00 \%$ & $30,00 \%$ & $100 \%$ \\
\hline CAC40 & 20 & 14 & 6 & $70,00 \%$ & $30,00 \%$ & $100 \%$ \\
\hline DAX & 20 & 14 & 6 & $70,00 \%$ & $30,00 \%$ & $100 \%$ \\
\hline DJIA & 22 & 15 & 7 & $68,18 \%$ & $31,82 \%$ & $100 \%$ \\
\hline DJTA & 25 & 17 & 8 & $68,00 \%$ & $32,00 \%$ & $100 \%$ \\
\hline DJUA & 27 & 18 & 9 & $66,67 \%$ & $33,33 \%$ & $100 \%$ \\
\hline EOE & 45 & 30 & 15 & $66,67 \%$ & $33,33 \%$ & $100 \%$ \\
\hline FTSE100 & 45 & 29 & 16 & $64,44 \%$ & $35,56 \%$ & $100 \%$ \\
\hline Hang Seng & 43 & 27 & 16 & $62,79 \%$ & $37,21 \%$ & $100 \%$ \\
\hline MEX-IPC & 45 & 28 & 17 & $62,22 \%$ & $37,78 \%$ & $100 \%$ \\
\hline Nasdaq & 23 & 14 & 9 & $60,87 \%$ & $39,13 \%$ & $100 \%$ \\
\hline All-Ord & 25 & 15 & 10 & $60,00 \%$ & $40,00 \%$ & $100 \%$ \\
\hline Nikkei & 21 & 12 & 9 & $57,14 \%$ & $42,86 \%$ & $100 \%$ \\
\hline Russel & 16 & 9 & 7 & $56,25 \%$ & $43,75 \%$ & $100 \%$ \\
\hline SMI & 18 & 10 & 8 & $55,56 \%$ & $44,44 \%$ & $100 \%$ \\
\hline SP500 & 20 & 11 & 9 & $55,00 \%$ & $45,00 \%$ & $100 \%$ \\
\hline TSE & 13 & 7 & 6 & $53,85 \%$ & $46,15 \%$ & $100 \%$ \\
\hline WIG & 25 & 13 & 12 & $52,00 \%$ & $48,00 \%$ & $100 \%$ \\
\hline
\end{tabular}

Source: own calculations

Table 7 presents the percentage of positive monthly rates of return in December in the decreasing order. All of the analyzed cases proved that, the percentage of positive returns was greater than $50 \%$. The highest percentage of positive rates of return was recorded for FTSE100 index $-86,96 \%$. On the second and third place were classified respectively DJUA $(85,00 \%)$ and TSE $(84,62 \%)$. The least positive monthly rates of return were registered in the case of Chinese B-Shares index $-58,82 \%$ of all observations. It is worth noting that the first seven positions in Table 7 are occupied by indices of developed countries. The first emerging markets index in the table 7 is Mexican Stock Exchange index (MEX-IPC), for which positive monthly return were recorded in $76,19 \%$ of all observations. Regarding Warsaw Stock Exchange positive monthly return occurred in $66,67 \%$ of the analyzed observations. 
Table 7. Number and percentage of positive and negative rates of return in December for the analyzed stock indices sorted in descending order for the percentage of positive returns

\begin{tabular}{|c|c|c|c|c|c|c|}
\hline Index & $\begin{array}{c}\text { Total number of } \\
\text { calculated } \\
\text { monthly returns }\end{array}$ & $\begin{array}{c}\text { Number of } \\
\text { positive monthly } \\
\text { returns }\end{array}$ & $\begin{array}{c}\text { Number of } \\
\text { negative monthly } \\
\text { returns }\end{array}$ & $\begin{array}{l}\text { Percentage of } \\
\text { positive monthly } \\
\text { returns }\end{array}$ & $\begin{array}{c}\text { Percentage of } \\
\text { negative monthly } \\
\text { returns }\end{array}$ & Sum \\
\hline FTSE 100 & 23 & 20 & 3 & $86,96 \%$ & $13,04 \%$ & $100,00 \%$ \\
\hline DJUA & 20 & 17 & 3 & $85,00 \%$ & $15,00 \%$ & $100,00 \%$ \\
\hline TSE & 26 & 22 & 4 & $84,62 \%$ & $15,38 \%$ & $100,00 \%$ \\
\hline DAX & 20 & 16 & 4 & $80,00 \%$ & $20,00 \%$ & $100,00 \%$ \\
\hline EOE & 20 & 16 & 4 & $80,00 \%$ & $20,00 \%$ & $100,00 \%$ \\
\hline Russel & 14 & 11 & 3 & $78,57 \%$ & $21,43 \%$ & $100,00 \%$ \\
\hline All-Ord & 26 & 20 & 6 & $76,92 \%$ & $23,08 \%$ & $100,00 \%$ \\
\hline MEX-IPC & 21 & 16 & 5 & $76,19 \%$ & $23,81 \%$ & $100,00 \%$ \\
\hline SP500 & 45 & 34 & 11 & $75,56 \%$ & $24,44 \%$ & $100,00 \%$ \\
\hline Bovespa & 20 & 15 & 5 & $75,00 \%$ & $25,00 \%$ & $100,00 \%$ \\
\hline SMI & 20 & 15 & 5 & $75,00 \%$ & $25,00 \%$ & $100,00 \%$ \\
\hline Hang Seng & 28 & 20 & 8 & $71,43 \%$ & $28,57 \%$ & $100,00 \%$ \\
\hline DJIA & 45 & 32 & 13 & $71,11 \%$ & $28,89 \%$ & $100,00 \%$ \\
\hline AMEX & 20 & 14 & 6 & $70,00 \%$ & $30,00 \%$ & $100,00 \%$ \\
\hline CAC40 & 20 & 14 & 6 & $70,00 \%$ & $30,00 \%$ & $100,00 \%$ \\
\hline DJTA & 20 & 14 & 6 & $70,00 \%$ & $30,00 \%$ & $100,00 \%$ \\
\hline Buenos & 19 & 13 & 6 & $68,42 \%$ & $31,58 \%$ & $100,00 \%$ \\
\hline Nikkei & 45 & 30 & 15 & $66,67 \%$ & $33,33 \%$ & $100,00 \%$ \\
\hline WIG & 24 & 16 & 8 & $66,67 \%$ & $33,33 \%$ & $100,00 \%$ \\
\hline BUX & 20 & 13 & 7 & $65,00 \%$ & $35,00 \%$ & $100,00 \%$ \\
\hline Nasdaq & 44 & 26 & 18 & $59,09 \%$ & $40,91 \%$ & $100,00 \%$ \\
\hline B-Shares & 17 & 10 & 7 & $58,82 \%$ & $41,18 \%$ & $100,00 \%$ \\
\hline
\end{tabular}

Source: own calculations

Now let us consider the following investment strategy. We build our investment portfolio replicating the specific stock index during the last session in December at the close prices, and sell it at the last session in following January, at the close prices (December January portfolio). A similar investment strategies are applied concerning investment portfolios that were formed during the last session in November and closed on the last session in December (November - December portfolio). During the remaining months, the financial resources are stored on an interest-free deposit. The 16 years long compound rates of return for each of the indices, except that for which the database is shorter than 16 years (Russell index), is presented in Table 8. 
Table 8. The compound rates of return for the strategy of opening long position during the last session in December (November) at close prices and selling it during the last session in January (December) at close prices, in the period 1999-2014

\begin{tabular}{|c|c|c|c|}
\hline Index & $\begin{array}{l}\text { Compound rates of return for } \\
\text { December - January portfolio }\end{array}$ & Index & $\begin{array}{c}\text { Compound rates of return for } \\
\text { November - December portfolio }\end{array}$ \\
\hline Buenos & $212,36 \%$ & Buenos & $145,09 \%$ \\
\hline BUX & $65,40 \%$ & Bovespa & $111,97 \%$ \\
\hline B-Shares & $60,69 \%$ & MEX-IPC & $88,42 \%$ \\
\hline WIG & $30,69 \%$ & B-Shares & $76,45 \%$ \\
\hline Bovespa & $15,16 \%$ & Nikkei & $52,62 \%$ \\
\hline Nasdaq & $13,99 \%$ & DJUA & $48,35 \%$ \\
\hline TSE & $11,41 \%$ & DAX & $46,56 \%$ \\
\hline MEX-IPC & $4,37 \%$ & EOE & $43,43 \%$ \\
\hline All-Ord & $-2,44 \%$ & BUX & $42,13 \%$ \\
\hline DJUA & $-8,46 \%$ & TSE & $39,68 \%$ \\
\hline SP500 & $-9,80 \%$ & WIG & $38,93 \%$ \\
\hline DAX & $-10,55 \%$ & DJTA & $36,99 \%$ \\
\hline SMI & $-11,02 \%$ & $\mathrm{CAC} 40$ & $32,37 \%$ \\
\hline CAC40 & $-11,24 \%$ & FTSE 100 & $32,11 \%$ \\
\hline DJIA & $-16,28 \%$ & Nasdaq & $28,39 \%$ \\
\hline DJTA & $-16,28 \%$ & SP500 & $23,77 \%$ \\
\hline AMEX & $-16,95 \%$ & DJIA & $23,54 \%$ \\
\hline Nikkei & $-17,27 \%$ & Hang Seng & $23,30 \%$ \\
\hline EOE & $-19,53 \%$ & All-Ord & $22,58 \%$ \\
\hline Hang Seng & $-25,06 \%$ & AMEX & $17,96 \%$ \\
\hline FTSE100 & $-29,40 \%$ & SMI & $10,79 \%$ \\
\hline
\end{tabular}

Source: own calculations

The compound rates of return for the December - January portfolio was positive in 8 out of the 21 analyzed indices, i.e. approximately in $38 \%$ of all cases, while in the remaining 13 cases was lower than zero. The highest compound rate of return was registered in the case of Buenos index $-212,36 \%$. On the second and third place were classified the compound rates of return for: BUX $(65,40 \%)$ and B-Shares index $(60,69 \%)$. The worst result with the use of this strategy was observed for FTSE100 - loss of $29,4 \%$.

The November - December strategy resulted to be more effective - all compound returns were positive. The highest rate of return was recorded, as for the December - January strategy, in the case of Buenos index, which amounted to $145,09 \%$. On the second and the third position other Hispanic stock exchange indexes were classified: Bovespa $(111,97 \%)$ and MEX-IPC $(88,42 \%)$. The worst result was achieved for portfolio replicating SMI index - in this case the compound rate of return was equal to $10,79 \%$. The strategy generated profit equal to $38,93 \%$ for Warsaw Stock Exchange index. 
Table 9. The correlation coefficient of January and December monthly rates of return between WIG and analyzed foreign exchange indices.

\begin{tabular}{|c|c|c|}
\hline Index & $\begin{array}{c}\text { Correlation coefficient } \\
\text { in January }\end{array}$ & $\begin{array}{c}\text { Correlation coefficient in } \\
\text { December }\end{array}$ \\
\hline All-Ord & 0,66 & 0,42 \\
\hline AMEX & 0,19 & 0,36 \\
\hline B-Shares & $-0,11$ & $-0,09$ \\
\hline Bovespa & 0,56 & 0,44 \\
\hline Buenos & $-0,06$ & 0,05 \\
\hline BUX & $-0,18$ & 0,61 \\
\hline $\mathrm{CAC} 40$ & 0,35 & 0,56 \\
\hline DAX & $-0,23$ & 0,58 \\
\hline DJIA & 0,59 & 0,28 \\
\hline DJTI & 0,16 & 0,49 \\
\hline DJUA & 0,04 & 0,03 \\
\hline EOE & 0,30 & 0,42 \\
\hline FTSE 100 & 0,11 & 0,61 \\
\hline Hang Seng & $-0,28$ & 0,82 \\
\hline MEX-IPC & $-0,20$ & 0,61 \\
\hline Nasdaq & $-0,41$ & 0,35 \\
\hline Nikkei & 0,62 & 0,08 \\
\hline Russel & 0,65 & 0,23 \\
\hline SMI & 0,20 & 0,27 \\
\hline SP500 & 0,43 & 0,23 \\
\hline TSE & 0,70 & 0,41 \\
\hline
\end{tabular}

Source: own calculations

The correlation coefficients of monthly returns in January and December between analyzed indices and WIG index are presented in Table 9. The value of the correlation coefficient in January was higher than 0,6 and was recorded for the following indices: All-Ord $(0,66)$, Nikkei $(0,62)$, Russel $(0,65)$ and TSE $(0,70)$. The negative correlation coefficient was obtained for the successive indices: B-Shares $(-0,11)$, Bueonos $(-0,06)$, BUX $(-0,18)$, DAX $(-0,23)$, Hang Seng $(-0,28)$, MEX-IPC $(-0,20)$ and Nasdaq $(-0,41)$. It should be noted that the negative value of the correlation coefficient in January between WIG and BUX indices, as well as relatively high negative correlation coefficient between WIG and two following indices: Nasdaq $(-0,41)$ and DAX $(-0,23)$. This fact proves the hypothesis that external cash flows are not flowing onto the Polish and Hungarian stock exchange in the same moments in January, although both countries constitute parts of emerging markets. On the other hand, the negative values of the correlation coefficients, according to the modern portfolio theory, permit investors to build more efficient portfolios.

Comparison of correlation coefficients between WIG and analyzed foreign indices in December, showed that the value of the ratio was negative only in the case of B-Shares Index $(-0,09)$, while for the other indices was positive. The values of the correlation coefficients higher than 0,6 were obtained for following indices: $\operatorname{BUX}(0,61)$, FTSE $(0,61)$, 
MEX-IPC $(0,61)$. The high value of the correlation coefficient in the month of December calculated for WIG and BUX index, equal to 0,61 allow to present the conclusion that the potential inflows of foreign investment funds onto Hungarian and Polish stock exchanges took place in the same periods of time in December.

\section{CONCLUSIONS}

In financial literature, the presence of the January effect and investors' convincement that the average rates of return of the stock index replicating portfolio is greater than zero in that month, seem to be strongly rooted. Meanwhile, the results obtained in this analysis confirmed the presence of returns statistically different from zero, only if the case of two stock indices, i.e. Nasdaq and BUX. An undoubted surprise, as well as the added value of this paper is the demonstration of the presence of rates of return, statistically different from zero, for stock index replicating portfolios in December. Calculations have shown the presence of the December effect for the following 15 stock indices: All-Ord, BUX, CAC40, DJIA, DJTA, DJUA, EOE, FTSE100, MEX-IPC, Nasdaq, Nikkei, Russel, SP500, TSE and WIG. Thus, it has been proved that for the analyzed stock indices, the seasonal effect was more frequent in December than in January, the latter is well known and widely described in scientific literature. This may provide an important evidence in determining investment strategy by investment funds or pension funds. Moreover it can also be used as a voice in the ongoing debate about the effectiveness of selected world financial markets. The obtained results confirm, to a certain extent, the results of previous studies conducted among others by Rozeff and Kinney ${ }^{102}$, Corhay et al. ${ }^{103}$, Clare et al. ${ }^{104}$ and Gultekin and Gultekin ${ }^{105}$ or Bernstein ${ }^{106}$.

Further empirical analysis should be carried out in two directions. Firstly, to determine the statistical significance of rates of return on the selected financial markets in other months than analyzed returns in January and December. Secondly, the research should be extended to other world exchange indices.

\section{LITERATURE}

[1] Aggarwal R., Hiraki T., Rao P, Regularities in Tokyo stock exchange security returns: P/E, size and seasonal influences, "Journal of Financial Research" 1990/13, p. 249-263.

[2] Agrawal A., Tandon K., Anomalies or illusions? Evidence from stock markets in eighteen countries, "Journal of International Money and Finance" 1994/13, p. 83-106.

[3] Al-Khazali O., Koumanakos E., Pyun C., Calendar anomaly in the Greek stock market: stochastic dominance analysis, "International Review of Financial Analysis" 2008/3, p. 461-474.

[4] Ariel R., A monthly effect in stock returns, "Journal of Financial Economics" 1987/17, p. 161-174.

[5] Ariel R., High stock returns before holidays: existence and evidence on possible causes, "Journal of Finance" 1990/45, p. 1611-1626.

[6] Asteriou D., Kovetsos G., Testing for the existence of the January effect in transition economies, "Applied Financial Economic Letters" 2006/2, p. 161-174.

\footnotetext{
${ }^{102}$ M. Rozeff, W. Kinney, op. cit., 379-402.

${ }^{103}$ A. Corhay, G. Hawawini, P. Michel, op. cit.

104 A. Clare A., Z. Psaradakis, S. Thomas, An analysis of seasonality in the UK equity market. "Economic Journal" 1995/105, p. 398-409.

${ }^{105}$ M. Gultekin, B. Gultekin, op. cit.,, p. 469-481.

${ }^{106}$ J. Bernsten, op. cit.
} 
[7] Banz R., The relationship between return and market value of common stocks, "Journal of Financial Economics" 1981/9, p. 3-18.

[8] Barone E., The Italian stock market: efficiency and calendar anomalies, "Journal of Banking and Finance" 1990/14, p. 483-510.

[9] Bekaert G., Harvey C., Foreign speculators and emerging equity markets, "Journal of Finance" 2000/2, p. 565-614.

[10] Bernsten J., Cycles of profit, Harpercolins, New York 1991.

[11] Bildisk R., Are calendar anomalies still alive? Evidence form Istanbul Stock Exchange, "Istanbul Stock Exchange" 2004.

[12] Board J., Sutcliffe C., The weekend effect in UK stock market returns, "Journal of Business, Finance and Accounting" 1988/5, p. 199-213.

[13] Buczek S., Efektywność informacyjna rynków akcji. Teoria a rzeczywistość, Szkoła Główna Handlowa w Warszawie, Warszawa 2005.

[14] Cadsby C., Ratner M., Turn-of-month and pre-holiday effects on stock returns: some international evidence, "Journal of Banking and Finance" 1992/16, p. 497-509.

[15] Chang C., Pinegar L., Seasonal fluctuations in industrial production and stock market seasonals, "Journal of Financial and Quantitative Analysis" 1989/24, p. 59-75.

[16] Chang C., Pinegar L., Stock market seasonal and prespecified multifactor pricing relations, "Journal of Financial and Quantitative Analysis" 1990/25, p. 517-533.

[17] Chen H., Singal V., Role of speculative short sales in price formation: case of the weekend effect, "Journal of Finance" 2003/4, p. 685-705.

[18] Choudhary T., Month of the year effect and January effect in pre-WWI stock returns: evidence from non-linear GARCH, "International Journal of Finance \& Economics", 2001/6, p. 1-11.

[19] Claessens S., Dasgupta S., Glenn J., Return behavior in emerging stock markets, "The World Bank Economic Review" 1995/1, p. 1-17.

[20] Clare A., Psaradakis Z., Thomas S., An analysis of seasonality in the UK equity market. "Economic Journal" 1995/105, p. 398-409.

[21] Condoyanni L., O'Hanlon J., Ward C., Day of the week effects on stock returns: international evidence, "Journal of Business Finance and Accounting" 1987/14, p. 159-174.

[22] Constantinides G., Optimal stock-trading with personal taxes: implications for prices and the abnormal January returns, "Journal of Financial Economics" 1984/13, p. 65-69.

[23] Corhay A., Hawawini G., Michel P., Stock market anomalies, Cambridge University Press, Cambridge 1988

[24] Coursey D., Dyl E., Price effects of trading interruptions in an experimental markets, University of Wyoming, Working Paper, March 1986.

[25] Coutts J., Hayes P., The weekend effect, the stock exchange account and the financial times industrial ordinary shares index 1987-1994, "Applied Financial Economics" 1999/9, p. 67-71.

[26] Cross F., The behavior of stock prices and Fridays and Mondays, "Financial Analyst Journal" 1973/29, p. 67-69.

[27] Czekaj J., Woś M., Żarnowski J., Efektywność giełdowa rynku akcji w Polsce, Wydawnictwo Naukowe PWN, Warszawa 2001.

[28] Dudzińska-Baryła R., Michalska E., Efekt miesiaca a behawioralne aspekty podejmowania Decyzji, [in:] Metody i Zastosowania Badań Operacyjnych, Wydawnictwo Uniwersytetu Ekonomicznego, Katowice 2010, p. 26-42.

[29] Dubois M., Louvet P., The day-of-the-week effect: the international evidence, "Journal of Banking and Finance" 1996/20, p. 1463-1484.

[30] Dyl E., Maberly D., A possible explanation of the weekend effect, "Financial Analyst Journal" 1998/44, p. 83-84.

[31] Fama E., Efficient capital markets; a review of theory and empirical work, "Journal of Finance" 1970/25, p. 483-417.

[32] Fields M., Security prices and stock exchange holidays in relation to short selling, "Journal of Business" 1934/7, p. 328-338. 
[33] Fountas S., Konstantinos S., Emerging stock markets return seasonalities: the January effect and the tax-loss selling hypothesis, "Applied Financial Economics" 2002/12, p. 291-299.

[34] French K., Stock returns and weekend effect, "Journal of Financial Economics" 1980/8, p. 55-69.

[35] Girardin E., Liu Z., Bank credit and seasonal anomalies in China stock markets, "China Economic Review" 2005/6, p. 465-483.

[36] Gu A., The declining January effect: evidence from U.S. equity markets, "Quarterly Review of Economics and Finance" 2003/2, p. 495-404.

[37] Gultekin M., Gultekin B., Stock market seasonality: international evidence, "Journal of Financial Economics" 1983/12, p. 469-481.

[38] Hamori S., Seasonality and stock returns; some evidence from Japan, "Japan and the World Economy" 2001/13, p. 463-481.

[39] Hasan T., Raj M., An examination of the tax loss selling behavior in a deregulated pacific financial market, "American Business Review" 2001/19, p. 100-105.

[40] Hirsch Y., Don't sell stock on Monday, Penguin Books, New York 1987.

[41] Ho Y., Stock returns seasonalities in Asia Pacific markets, "Journal of International Financial Management and Accounting" 1990/2, p. 47-77.

[42] Jaffie J., Westerfield R., Is there a monthly effect in common stock returns? Evidence from foreign countries, "Journal of Banking and Finance" 1989/13, p. 237-244.

[43] Jaffie J., Westerfield R., Ma C., A twist on Monday effect in stock prices: evidence from the US and foreign stock markets, "Journal of Banking and Finance" 1989/15, p. 641-650.

[44] Jajuga K., Jajuga T., Inwestycje, Wydawnictwo Naukowe PWN, Warszawa 2006.

[45] Kato K., Schallheim J., Seasonal and size anomalies in the Japanese stock market, "Journal of Financial and Quantitative Analysis" 1985/20, p. 243-260.

[46] Kato K., Schwarz S., Ziemba W., Day of the weekend effects in Japanese stocks, [in:] Japanese Capital Markets, Ballinger, New York 1990, p. 249-281.

[47] Keim D., Size-related anomalies and stock return seasonality: further empirical evidence, "Journal of Financial Economics" 1983/12, p. 13-32.

[48] Kelly F., Why you win or lose: the psychology of speculation, Houghton Mifflin, Boston 1930.

[49] Kim C., Park J., Holiday effects and stock returns: further evidence, "Journal of Financial and Quantitative Analysis" 1994/29, p. 13-32.

[50] Kohers T., Kohli R., The yearend effect in stock returns over business cycles: a technical note, "Journal of Economics and Finance" 1992/16, p. 61-68.

[51] Kramer C., Macroeconomic seasonality and the January effect, "Journal of Finance" 1994/49, p. $1883-1891$.

[52] Lakonishok J., Levi M., Weekend effect on stock returns: a note, "Journal of Finance" 1982/37, p. 883-889.

[53] Lakonishok J., Maberly E., The weekend effect: trading patterns of individual and institutional investors, "Journal of Finance" 1990/45, p. 231-243.

[54] Lakonishok J., Shmidt S., Are seasonal anomalies real. A ninety-year perspective, "Review of Financial Studies" 1988/1, p. 403-425.

[55] Lauterbach B., Ungar M., Calendar anomalies: some perspectives from the behavior of the Israeli stock market, "Applied Financial Economics" 1992/2, p. 57-60.

[56] Li B., Liu B., Monthly seasonality in the New Zealand stock market, "International Journal of Business, Management and Economic Research" 2010/1, p. 1116-1121.

[57] Ligon J., A simultaneous test of competing theories regarding the January effect, "Journal of Financial Research"1997/20, p. 13-32.

[58] Longin F., Solnik B., Is the correlation in international equity returns constant: 1960-1990?, "Journal of International Money and Finance" 1995/1, p. 3-26.

[59] Lucey B., Whelan S., Monthly and semi-annual seasonality in the Irish equity market 19342000, "Applied Financial Economics" 2004/14, p. 203-208.

[60] Mills T., Coutts J., Calendar effects in the London Stock Exchange FTSE indices, "European Journal of Finance" 1995/1, p. 79-93. 
[61] Mills T., Siriopoulos C., Markellos R., Harizanis D., Seasonality in the Athens Stock Exchange, "Applied Financial Economics" 2000/10, p. 137-142.

[62] Moller N., Zilca S., The evolution of January effect, "Journal of Banking and Finance" 2008/32, p. 447-457.

[63] Mougoue M., Seasonalities in the Taiwanese stock market, "American Business Review" 1996/14, p. 73-79.

[64] Nassir A., Mohammad S., The January effect of stock trader in the Kuala Lumpur Stock Exchange: an empirical analysis, "Hong Kong Journal of Business Management" 1987/5, p. 35-50.

[65] Nowakowski J., Borowski K., Zastosowanie teorii Carolana i Fischera na rynku kapitałowym, Difin, Warszawa 2005.

[66] Ogden J., Turn-of month evaluations of liquid profits and stock returns: A common explanation for the monthly and January effects, ,Journal of Finance” 1990/45, p. 1259-1272.

[67] Officer R., Seasonality in Australian capital markets: market efficiency and empirical issues, "Journal of Financial Economics" 1975/2, p. 29-51.

[68] Peiro E., Daily seasonality in stock returns: Further international evidence, "Economics Letters" 1994/45, p. 227-232.

[69] Polwitoon P., Tawatnuntachai O., Emerging market bond funds: a comprehensive analysis, „Financial Review” 2008/1, p. 51-84.

[70] Poterba J., Weisbenner S., Capital gains tax rules, tax-loss trading, and turn-of-the-year returns, "Journal of Finance" 2001/56, p. 353-368.

[71] Raharjo A., Mabaraq F., Mundir F. December effect of stock market return in Indonesia Stock Exchange 1998-2012, "International Journal of Science and Research" 2013/2, p. 708-711.

[72] Raj M., Kumari D., Day-of-the-week and other market anomalies in the Indian stock market, "International Journal of Emerging Markets" 2006/1, p. 235-246.

[73] Raj M., Thurston D., January or April? Test of the turn-of-the-year-effect in the New Zealand stock market, "Applied Economics Letters" 1994/18, p. 81-83.

[74] Reinganum M., Ten anomalous stock market behavior of small firms in January: empirical tests for tax-loss selling effects, "Journal of Financial Economics" 1983/12, p. 89-104.

[75] Ritter J., An explanation to the turn of the year effect, University of Michigan, Graduate School of Business Administration, Working Paper 1987, http://dx.doi.org/10.2307/2328193.

[76] Ritter J., The buying and selling behavior of individual investors at the turn of the year, "Journal of Finance" 1988/43, p. 701-717.

[77] Rogalski M., Discussion to Keim i Stambaugh, "Journal of Finance" 1984/3, p. 1603-1614.

[78] Roll R., Vas is das? The turn-of-the-year effect and the return premia of small firms, "Journal of Portfolio Management" 1983/9, p. 18-28.

[79] Rozeff M., Kinney W., Capital market seasonality: the case of stock returns, "Journal of Financial Economics" 1976/3, 379-402.

[80] Schwert W., Anomalies and market efficiency, "Simon School of Business Working Paper" 2002/FR 02-13,

[81] Sias R., Starks L., Institutions and individuals at the turn-of-the-year, "Journal of Finance" 1997/52, p. 1543-1562.

[82] Simson E., Stock market anomalies, Cambridge University Press, Cambridge 1988.

[83] Solnik, B., Bosquet L., Day-of-the-week effect on the Paris Bourse, "Journal of Banking and Finance" 1990/14, p. 461-468.

[84] Suppa-Aim T., Mutual fund performance in emerging markets: the case of Thailand, University of Birmingham, Working paper 2010.

[85] Sutheebanjard P., Premchaiswadi W., Analysis of calendar effects: day-of-the-week effect on the Stock Exchange of Thailand (SET), "International Journal of Trade, Economics and Finance" 2010/1, p. 2010-2023.

[86] Szyszka A., Wycena papierów wartościowych na rynku kapitałowym w świetle finansów behawioralnych, Wydawnictwo Akademii Ekonomicznej w Poznaniu, Poznań 2007. 
[87] Thaler R., Seasonal movements in security prices II: weekend, holiday, turn of the month and intraday effects, "Journal of Economic Perspectives" 1987/1, p. 169-177.

[88] Theobald M., Prince V., Seasonality estimation in thin markets, "Journal of Finance" 1984/39, p. 377-392.

[89] Tinic S., West R., Seasonality in Canadian stock prices: a test of the tax-loss selling hypothesis, "Journal of Financial and Quantitative Analysis" 1987/22, p. 561-574.

[90] Wachtel B., Certain observations on seasonal movements in stock prices, "Journal of Business of the University of Chicago" 1943/15, p. 184-193.

[91] Zilca S., Moller N., The evolution of the January effect, "Journal of Banking and Finance" 2008/32, p. 447-457.

\section{ANALIZA MIESIĘCZNYCH STÓP ZWROTU W STYCZNIU I GRUDNIU NA PRZYKŁADZIE WYBRANYCH INDEKSÓW GIEŁD ŚWIATOWYCH}

\section{JEL Classification: $G 11, G 14$}

Na współczesnym rynku wciąż miedzy teoretykami a praktykami toczy się dyskusja na temat efektywności rynków. O ile ci pierwsi starają się wykazać efektywność rynków finansowych, o tyle druga grupa wyraża przekonanie, że rynki finansowe nie są efektywne. Przeprowadzenie dowodu pokazującego efektywność rynków finansowych byłoby jednocześnie dowodem na to, że zarządzający portfelami aktywów nie byliby w stanie uzyskać wyższej stopy niż portfel rynkowy w długim terminie. Jednym ze sposobów wykazania tezy o nieefektywności rynków finansowych jest m.in. badanie efektów kalendarzowych. Ich występowanie podważa bowiem teorię rynków efektywnych i pozwala na skonstruowanie strategii inwestycyjnej pozwalającej uzyskiwać nadwyżkowe stopy zwrotu (powyżej stopy zwrotu analizowanego indeksu giełdowego).

W artykule przedstawiono badanie efektywności 22 wybranych indeksów giełdowych przy zastosowaniu miesięcznych stóp zwrotu w styczniu i grudniu (odpowiednio tzw. efekt stycznia i efekt „rajdu św. Mikołaja”). Portfel replikujący określony indeks giełdowy nabyty został na ostatniej sesji w jednym miesiącu, a sprzedany również na ostatniej sesji w następnym (w cenach zamknięcia). Występowanie nieefektywności rynków wykazano w styczniu dla dwu indeksów: BUX i Nasdaq, a w grudniu dla 15 spośród 22 badanych indeksów: AllOrd, BUX, CAC40, DJIA, DJTA, DJUA, EOE, FTSE100, MEX-IPC, Nasdaq, Nikkei, Russel, SP500, TSE i WIG. Tym samym w wypadku niektórych indeksów potwierdzone zostały prace innych badaczy, a w wypadku innych, przeprowadzone badania należy uznać za pionierskie.

Słowa kluczowe: efektywność rynku; sezonowość rynków finansowych; anomalie rynkowe; efekt stycznia, efekt grudnia

\section{DOI: 10.7862/rz.2015.mmr.2}

Tekst złożono w redakcji: marzec 2015

Przyjęto do druku: marzec 2015 